\title{
EFFECTS OF PENTOXIFYLLINE ON TNF-ALPHA AND LUNG HISTOPATHOLOGY IN HCL-INDUCED LUNG INJURY
}

\author{
Itamar Souza de Oliveira-Júnior, Carla Cristina Maganhin, Adriana Aparecida \\ Ferraz Carbonel, Cristina Maria Rodrigues Monteiro, Sâmia Santos Cavassani, \\ Ricardo Martins Oliveira-Filho
}

\begin{abstract}
Oliveira-Júnior IS de, Maganhin CC, Carbonel AAF, Monteiro CMR, Cavassani SS, Oliveira-Filho RM. Effects of pentoxifylline on tnf-alpha and lung histophatology in hcl-induced lung injury. Clinics. 2008;63(1):77-84.
\end{abstract}

OBJECTIVE: To evaluate the effects of pentoxifylline on hydrochloric acid-induced lung lesions in rats subjected to mechanical ventilation.

METHODS: Twenty male, adult Wistar-EPM- 1 rats were anesthetized and randomly grouped ( $\mathrm{n}=5$ animals per group) as follows: control-MV (mechanical ventilation, $\mathrm{MV}$ group); bilateral instillation of $\mathrm{HCl}(\mathrm{HCl}$ group); bilateral instillation of $\mathrm{HCl}$ followed by pentoxifylline $(50 \mathrm{mg} / \mathrm{kg} \mathrm{bw})$ infusion ( $\mathrm{HCl}+\mathrm{PTX}$ group) and pentoxifylline infusion followed by bilateral instillation of $\mathrm{HCl}$ (PTX+HCl group). At 20, 30, 90 and 180 min after treatments, the blood partial pressures of $\mathrm{CO}_{2}$ and $\mathrm{O}_{2}$ were measured. The animals were euthanized, and bronchoalveolar lavages were taken to determine the contents of total proteins, corticosteroid and TNF- $\alpha$. Samples of lung tissue were used for histomorphometric studies and determining the wet-to-dry (W/D) lung weight ratio. RESULTS: In the MV group, rats had alveolar septal congestion, and, in the $\mathrm{HCl}$ group, a remarkable recruitment of neutrophils and macrophages into the alveoli was noticed; these events were reduced in the animals with PTX+HCl. The partial pressure of oxygen increased in $\mathrm{PTX}+\mathrm{HCl}$ animals $(121 \pm 5 \mathrm{mmHg})$ as compared with the $\mathrm{HCl}(62 \pm 6 \mathrm{mmHg})$ and $\mathrm{HCl}+\mathrm{PTX}(67 \pm 3 \mathrm{mmHg})$ groups within 30 minutes. TNF- $\alpha$ levels in bronchoalveolar lavage were significantly higher in the $\mathrm{HCl}$ group $(458 \pm 50 \mathrm{pg} / \mathrm{mL})$, reduced in the $\mathrm{HCl}+\mathrm{PTX}$ group $(329 \pm 45 \mathrm{pg} / \mathrm{mL})$ and lowest in the $\mathrm{PTX}+\mathrm{HCl}$ group $(229 \pm 41 \mathrm{pg} / \mathrm{mL})$. The levels of corticosteroid in bronchoalveolar lavage were significantly lower in the $\mathrm{HCl}(8 \pm 1.3 \mathrm{ng} / \mathrm{mL})$ and $\mathrm{HCl}+\mathrm{PTX}$ group $(16 \pm 2 \mathrm{ng} / \mathrm{mL})$ and were highest in the PTX $+\mathrm{HCl}(27 \pm 1.9 \mathrm{ng} / \mathrm{mL})$.

CONCLUSION: Pretreatment with PTX improves oxygenation, reduces TNF- $\alpha$ concentration and increases the concentration of corticosteroid in bronchoalveolar lavage upon lung lesion induced by $\mathrm{HCl}$.

KEYWORDS: Acid aspiration. Acute lung injury. Mechanical ventilation. Corticosteroid. Cytokine.

\section{INTRODUCTION}

Gastric acid aspiration is a common etiology of acute lung injury (ALI) and is initially characterized by a chemical "burn" of the pulmonary epithelium, with a subsequent influx of extracellular fluid into the alveolar space that

Surgery Center, Department of Surgery, Federal University of São Paulo (UNIFESP) - São Paulo/SP, Brazil.

souza.oliveira@unifesp.br

Received for publication on September 03, 2007.

Accepted for publication on October 05, 2007. leads to pulmonary edema. Acid aspiration-induced lung injury is an important cause of acute respiratory distress syndrome (ARDS), which has a high mortality rate. ${ }^{1,2}$

The effect of acid instillation into the lung has been extensively studied. ${ }^{4,5}$ Acid airway aspiration has been reported as the cause of $10 \%$ to $30 \%$ of all anesthetic-related deaths. ${ }^{6,7}$ Following aspiration, patients usually develop symptoms consistent with microvascular lung injury, such as pulmonary edema and decreased lung compliance, which ultimately lead to increased work for breathing, hypoxemia, damage to the alveolar-capillary membrane, increased al- 
veolar protein content and induced pulmonary macrophage accumulation. ${ }^{8,9}$ Tissue cytokine levels may be directly associated with further accumulation and activation of pulmonary macrophages, thus increasing lung injury. Cytokines mediate the induction and amplification of the inflammatory response to various types of injury, including hemorrhagic and endotoxic shock. ${ }^{10}$

Critical illness, such as trauma, pneumonia, sepsis, and major surgery, is accompanied by activation of the hypothalamus-pituitary-adrenal (HPA) axis. Serum adrenocorticotropic hormone (ACTH) and glucocorticoid concentrations are increased, and activation of this axis appears to be an important component of the general adaptation to stress. ${ }^{11}$

Normal activation and functioning of the HPA axis have an important role in modulating the response to critical illness and systemic inflammation. ${ }^{11} \mathrm{~A}$ deficiency in the HPA axis could lead to unchecked or ongoing activation of inflammatory mediators, cardiovascular instability, loss of vascular integrity and possible persistent airspace inflammation and injury, which would lead to an exuberant postinjury fibroproliferative response in the lung. ${ }^{12}$ The factors determining glucocorticoid response at the receptor and molecular level are complex and probably explain the individual variation and tissue specificity in systemic response. ${ }^{13}$ Basal circulating concentrations of glucocorticoids are complex and have also been observed to be unchanged, ${ }^{14}$ increased $^{15}$ or decreased ${ }^{16}$ in rodents. Corticosterone measurements were performed using the plasma, urine and excrement from these animals. Unfortunately, we did not find detail in the literature about the measurement in broncoalveolar lavage (BAL).

Pentoxifylline (PTX) is a nonselective phosphodiesterase inhibitor with important immuno-regulatory actions. Its anti-inflammatory properties have recently been investigated by the ARDS Clinical Trials Network in a large, prospective, placebo-controlled multicenter study ${ }^{17}$ in addition to other experimental studies. ${ }^{18}$

This study was designed to further analyze the effects of PTX treatment immediately before and after hydrochloric acid instillation $(\mathrm{HCl})$. To accomplish this, we determined protein leakage, tumor necrosis factor-alpha (TNFa) and corticosteroid concentrations in BALs and lung wetto-dry ratios.

\section{MATERIALS AND METHODS}

\section{Surgical Procedure}

All procedures were approved by the Institutional Research Committee at Federal University of São Paulo, in accordance with the National Institutes of Health (NIH) Guidelines Regarding Animal Experimentation.

Twenty $(n=20)$ male Wistar rats weighing 268 to 312 $\mathrm{g}$ were fasted overnight with free access to water. Animals were group-housed in standard Plexiglas bins (2-3 rats per cage). Rats ( $n=5$ in every group) were anesthetized intraperitoneally (i.p.) with sodium thiopental $(40 \mathrm{mg} / \mathrm{kg}$ body weight, Thionembutal-ABBOTT, SP, Brazil). Muscle relaxation was maintained with $0.8 \mathrm{mg} / \mathrm{kg}$ pancuronium bromide (Pavulon-Organon, São Paulo, Brazil) i.p. Animals were placed in the supine position, and $1 \%$ lidocaine was injected subcutaneously at the tracheal region.

After anesthesia, a tracheotomy was performed, and a $14 \mathrm{G}$ cannula was inserted approximately $1 \mathrm{~cm}$ above the carina. A hind paw vein (used for drug infusions and compensation of fluid losses) and the left internal carotid artery (used to obtain arterial blood for gases determination) were exposed and cannulated using PE-50 tubing (Intramedic Polyethylene Tubing, Becton Dickinson, NJ, USA). Normothermia was maintained with an underlying electric hotplate $\left(37 \pm 0.6^{\circ} \mathrm{C}[\right.$ mean $\left.\pm \mathrm{SD}]\right)$.

\section{Mechanical Ventilation}

After reaching a surgical plane of anesthesia and muscle relaxation, the animals were ventilated using a rodent ventilator (683 model, Harvard Apparatus; Holliston, MA, USA) for $3 \mathrm{~h}$ using a tidal volume $\left(\mathrm{V}_{T}\right)$ established at approximately $6 \mathrm{~mL} / \mathrm{kg}$, a positive end-expiratory pressure (PEEP) of $5 \mathrm{cmH}_{2} \mathrm{O}$, a fraction of inspired oxygen $\left(\mathrm{FiO}_{2}\right)$ of 1.0, a respiratory rate (RR) of 30-50 bpm and an inspiration/expiration (I/E) ratio of 1:2. A venous catheter was placed in the jugular vein to allow the infusion of isotonic saline solution and sodium pentobarbital whenever needed.

Groupings: Animals were divided into 4 different groups ( $\mathrm{n}=5$ in each group). The first group (Control-MV) received only mechanical ventilation; the second group $(\mathrm{HCl})$ received hydrochloric acid instillation; the third group $(\mathrm{HCl}+\mathrm{PTX})$ received $\mathrm{HCl}$ instillation followed by PTX infusion; and the fourth group $(\mathrm{PTX}+\mathrm{HCl})$ received PTX infusion 10 min prior to $\mathrm{HCl}$ instillation.

Acid Instillation Lung Injury: After 10 min connected in the ventilator for stabilization, the lung injury was performed using a $0.1 \mathrm{~N} \mathrm{HCl}$ solution $(2 \mathrm{~mL} / \mathrm{kg})$ instilled through a side port adaptor of the endotracheal tube during the inspiratory phase of respiration. Blood samples were collected 30 seconds before lung injury and the protocol was started.

Pentoxifylline administration: $\mathrm{HCl}+\mathrm{PTX}$ animals received $50 \mathrm{mg} / \mathrm{kg}$ PTX (Pentox, FARMASA, São Paulo, SP, Brazil) in a bolus after the lung injury induction. The ani- 
mals in the PTX $+\mathrm{HCl}$ group received the PTX infusion 10 min prior to instillation of $\mathrm{HCl}$. The PTX pre- or post- $\mathrm{HCl}$ instillation and $\mathrm{HCl}$ animals received PTX or normal saline through the tail vein ${ }^{18}$.

\section{Measurements}

Arterial blood gases measurement: Arterial blood gases (arterial partial pressure of oxygen $\left[\mathrm{Pa}_{\mathrm{O} 2}\right]$ and carbon dioxide $\left.\left[\mathrm{Pa}_{\mathrm{CO} 2}\right]\right)$ were determined in blood samples collected with sterile vented plastic syringes (PICO 70, Radiometer, Copenhagen, Denmark) and measured 20, 30, 90 and 180 min after initiation of MV using an automatic AVL-Compact3 device (Roche Diagnostic, Mannheim, Germany).

BAL: At the end of $3 \mathrm{~h}$, the animals were euthanized (1 mL/100 g bw T-61 Euthanasia Solution, Hoechst \& Roussel). A sternotomy was performed, and the lungs and appending structures were removed and weighed. The left lung was tied, and the right lung was washed three times with $30 \mathrm{~mL} / \mathrm{kg}$ cold sterile phosphate-buffered saline (PBS; $\mathrm{pH}$ 7.2-7.4). Lavage fluids were kept separate and centrifuged (at $400 \mathrm{x} \mathrm{g}$ for $10 \mathrm{~min}$ ) at $4{ }^{\circ} \mathrm{C}$, and the supernatants were frozen immediately on dry ice and stored at $-80^{\circ} \mathrm{C}$.

Protein leakage: A 1-mL aliquot of BAL was used to measure total protein using the Lowry method. ${ }^{18}$

W/D weight ratio of lungs: After bronchoalveolar lavage, the right lung was placed in a drying oven for $72 \mathrm{~h}$ at $60{ }^{\circ} \mathrm{C}$ and then re-weighed. The W/D ratios were then calculated.

Corticosteroid Detection: Corticosteroids were measured in duplicate using a radioimmunoassay (Coat-A-Count Rat Corticosteroid, DPC Diagnostic, CA, USA) in the BAL, according to the manufacturer's instructions, and the countings were performed using a Gamma Counter (Gamma Master 1277 model, LKB Wallac, Sweden). The assay sensitivity was $5.7 \mathrm{ng} / \mathrm{mL}$; the inter-assay and intraassay coefficients of variation were $4.8 \%$ to $5.8 \%$ and $4.0 \%$ to $4.3 \%$, respectively.

Cytokine Assay: TNF-a concentrations in BAL were determined using a rat-specific, commercially available enzyme immunoassay [ELISA] (R\&D Systems, Minneapolis, USA).

Histology and morphometry: Lungs were removed en bloc and inflated at a pressure of $20 \mathrm{cmH}_{2} \mathrm{O}$ with $4 \%$ paraformaldehyde in PBS at room temperature to fix the tissue. Left lung fragments were washed in $50 \mathrm{mM}$ phosphate buffer, $\mathrm{pH} 7.4$, dehydrated in graded concentrations of ethanol and then embedded in paraffin. From each lung, $4 \mu \mathrm{m}$ sections were obtained and stained with hematoxylin and eosin (HE) to evaluate lung morphology and morphom- etry. The slides were systematically scanned in a microscope using a 400X magnification. Macrophage and neutrophil counts were performed in the alveolar lumen septae by image capture with a light microscope using 400X magnification (Axiolab Standart 2.0, Carl Zeiss) coupled to a video camera (AxionCam, Carl Zeiss).

\section{STATISTICAL ANALYSIS}

Data were expressed as means \pm standard deviation (SD). Values were compared between groups using an ANOVA test for multiple comparisons, and repeated-measures ANOVA was used to compare measurements within groups along the different time periods. Statistical analyses were performed using a standard computer software package (GraphPad Prisma, GraphPad Software, San Diego, CA, USA). $P$-values less than 0.05 were considered statistically significant.

\section{RESULTS}

\section{Blood Gases Analyses}

In the $\mathrm{HCl}$ and $\mathrm{HCl}+\mathrm{PTX}$ groups, the $\mathrm{Pa}_{\mathrm{O} 2}$ values decreased after $30 \mathrm{~min}(62 \pm 6.1 \mathrm{mmHg}$ and $67 \pm 3.4 \mathrm{mmHg}$, respectively, Table 1), and $\mathrm{Pa}_{\mathrm{O} 2}$ values were higher in the $\mathrm{PTX}+\mathrm{HCl}$ group $[121 \pm 5.3 \mathrm{mmHg}$ at $30 \mathrm{~min} ; 287 \pm 7 \mathrm{mmHg}$ at $90 \mathrm{~min}$; and $377 \pm 12.4$ at $180 \mathrm{~min}$ ] compared to the $\mathrm{HCl}$ and HCL+PTX groups in the same time point (Table 1). $\mathrm{Pa}_{\mathrm{CO} 2}$ values were higher in the $\mathrm{HCl}$ and $\mathrm{HCl}+\mathrm{PTX}$ groups compared to the Control-MV and $\mathrm{PTX}+\mathrm{HCl}$ groups ( $\mathrm{Ta}-$ ble 1) after 30,90 and $180 \mathrm{~min}$. No significant differences were observed among groups at the 20 min time point.

\section{W/D weight of lungs, total proteins, TNF- $\alpha$ and corticosterone in the BAL}

W/D ratios were higher in the $\mathrm{HCl}$ group as compared to the $\mathrm{HCl}+\mathrm{PTX}$ and $\mathrm{PTX}+\mathrm{HCl}$ groups; and the W/Ds were lower in the $\mathrm{PTX}+\mathrm{HCl}$ animals compared with the $\mathrm{HCl}+\mathrm{PTX}$ group (Table 2).

The total proteins in BAL decreased in the $\mathrm{PTX}+\mathrm{HCl}$ group compared to $\mathrm{HCl}+\mathrm{PTX}[28 \pm 2.5 \mathrm{mg} / \mathrm{mL}$ versus $36 \pm 3.1 \mathrm{mg} / \mathrm{mL}$, respectively]. In the Control-MV group, the total protein values in BAL were $20.4 \pm 0.6 \mathrm{mg} / \mathrm{mL}$ (Table 2).

The TNF- $\alpha$ concentration in BAL was significantly higher from $458.4 \pm 50.5 \mathrm{pg} / \mathrm{mL}[\mathrm{HCl}]$ to $329.4 \pm 44.9 \mathrm{pg} / \mathrm{mL}$ $[\mathrm{HCl}+\mathrm{PTX}]$ and 229.4 $\pm 41.1 \mathrm{pg} / \mathrm{mL}[\mathrm{PTX}+\mathrm{HCl}](p<0.001)$ (Figure 1).

The corticosterone level in the BAL (Figure 2) was 
Table 1 - Pentoxifylline (PTX) and hydrochloric acid (HCl) effects on the arterial blood levels of $\mathrm{Pa}_{\mathrm{O} 2}$ and $\mathrm{Pa}_{\mathrm{CO} 2}$ at 20, 30, 90 and 180 minute time points. Data are shown as mean \pm SD.

\begin{tabular}{lcccccccc}
\hline & \multicolumn{4}{c}{$\mathrm{Pa}_{\mathrm{O} 2}(\mathrm{mmHg})$} & \multicolumn{3}{c}{$\mathrm{Pa}_{\mathrm{CO} 2}(\mathrm{mmHg})$} \\
& $20 \mathrm{~min}$ & $30 \mathrm{~min}$ & $90 \mathrm{~min}$ & $180 \mathrm{~min}$ & $20 \mathrm{~min}$ & $30 \mathrm{~min}$ & $90 \mathrm{~min}$ & $180 \mathrm{~min}$ \\
\hline $\mathrm{C}-\mathrm{MV}$ & $124 \pm 3.6$ & $288 \pm 11.1^{\mathrm{a}}$ & $356 \pm 7.2^{\mathrm{b}}$ & $397 \pm 8.3^{\mathrm{c}}$ & $38 \pm 3.1$ & $36 \pm 1.5^{\mathrm{a}}$ & $36 \pm 1.3^{\mathrm{b}}$ & $37 \pm 2.3^{\mathrm{c}}$ \\
$\mathrm{HCl}$ & $127 \pm 1.8$ & $62 \pm 6.1$ & $177 \pm 6.6$ & $127 \pm 4.7$ & $36 \pm 3$ & $54 \pm 2.5$ & $55 \pm 2.6$ & $61 \pm 4$ \\
$\mathrm{HCl}+\mathrm{PTX}$ & $118 \pm 6.7$ & $67 \pm 3.4$ & $114 \pm 7.5$ & $254 \pm 14.6$ & $39 \pm 2.4$ & $54 \pm 1.5$ & $49 \pm 0.8$ & $53 \pm 2.9$ \\
PTX+HCl & $121 \pm 7.1$ & $121 \pm 5.3^{*}$ & $287 \pm 7^{\#}$ & $377 \pm 12.4^{*}$ & $36 \pm 0.8$ & $50 \pm 2.0^{*}$ & $45 \pm 3.8^{\S}$ & $46 \pm 5.1^{\ddagger}$ \\
\hline
\end{tabular}

No differences were observed at the 20 minute time point in the $\mathrm{Pa}_{\mathrm{O}_{2}}$ and $\mathrm{Pa}_{\mathrm{CO}_{2}}$ levels among all groups.

* $\mathrm{p}<0.05$ compared with $\mathrm{HCl}$ and $\mathrm{HCl}+\mathrm{PTX}$ groups in the $\mathrm{Pa}_{\mathrm{O}_{2}}$ and $\mathrm{Pa}_{\mathrm{CO}_{2}}$ measurements (30 min); ${ }^{\#} \mathrm{p}<0.05$ compared with $\mathrm{HCl}$ and $\mathrm{HCl}+\mathrm{PTX}$ groups in the $\mathrm{Pa}_{\mathrm{O}_{2}}$ measurements $(90 \mathrm{~min}$ );

${ }^{8} \mathrm{p}<0.05$ compared with $\mathrm{HCl}$ group in the $\mathrm{PaC}_{\mathrm{O}_{2}}$ measurement $(90 \mathrm{~min}$ );

${ }^{*} \mathrm{p}<0.05$ compared with $\mathrm{HCl}$ and $\mathrm{HCl}+\mathrm{PTX}$ groups in the $\mathrm{Pa}_{\mathrm{O}_{2}}$ and $\mathrm{Pa}_{\mathrm{CO}_{2}}$ measurements (180 min);

${ }^{a} \mathrm{p}<0.05$ compared with all other groups in the $\mathrm{Pa}_{\mathrm{O}_{2}}$ and $\mathrm{Pa}_{\mathrm{CO}_{2}}$ measurements $(30 \mathrm{~min})$;

${ }^{\mathrm{b}} \mathrm{p}<0.05$ compared with all other groups in the $\mathrm{Pa}_{\mathrm{O}_{2}}$ and $\mathrm{Pa}_{\mathrm{CO}_{2}}$ measurements $(90 \mathrm{~min}$ );

${ }^{c} \mathrm{p}<0.05$ compared with all other groups in the $\mathrm{Pa}_{\mathrm{O}_{2}}$ and $\mathrm{Pa}_{\mathrm{CO}_{2}}$ measurements $(180 \mathrm{~min})$.

Table 2 - Effects of pentoxifylline (PTX) treatment before or after hydrochloric acid $(\mathrm{HCl})$ instillation on the levels of total protein (TP) in bronchoalveolar lavage and wet-to-dry ratio (W/D). Data are shown as mean \pm SD.

\begin{tabular}{lcccc}
\hline & Control-MV & $\mathrm{HCl}$ & $\mathrm{HCl}+\mathrm{PTX}$ & $\mathrm{PTX}+\mathrm{HCl}$ \\
\hline TP $(\mathrm{mg} / \mathrm{mL})$ & $20.4 \pm 0.6$ & $49.6 \pm 4.3^{*}$ & $36 \pm 3.1$ & $28 \pm 2.5^{\#}$ \\
W/D $(\mathrm{g})$ & $9.4 \pm 1.3$ & $14 \pm 1.4^{*}$ & $11.2 \pm 1.8$ & $8.6 \pm 0.5^{\#}$ \\
\hline
\end{tabular}

${ }^{*} \mathrm{p}<0.05$ compared with Control, $\mathrm{HCl}+\mathrm{PTX}$ and $\mathrm{PTX}+\mathrm{HCl}$.

${ }^{*} \mathrm{p}<0.05$ compared with $\mathrm{HCl}$ and $\mathrm{HCl}+\mathrm{PTX}$.

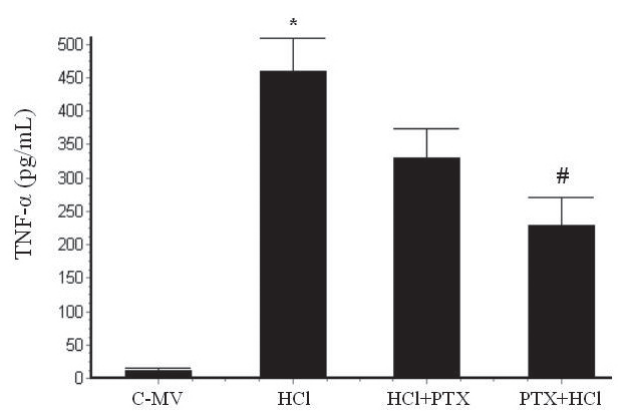

Figure 1 - Effect of pentoxifylline (PTX) on TNF-a levels in BAL from rats with mechanically ventilated controls (C-MV) and instilled with $\mathrm{HCl} .{ }^{*} p<0.05$ versus the $\mathrm{HCl}+\mathrm{PTX}$ and $\mathrm{PTX}+\mathrm{HCl}$ groups, and ${ }^{*} \mathrm{p}<0.05$ versus the $\mathrm{HCl}$ and the $\mathrm{HCl}+\mathrm{PTX}$ groups. Values are presented as mean $\pm \mathrm{SD}$.

higher in the Control-MV group $(41.4 \pm 5.2 \mathrm{ng} / \mathrm{mL} ; p<0.001)$ compared to all other groups. The corticosterone concentrations were lower in the $\mathrm{HCl}$ group $(7.6 \pm 1.3 \mathrm{ng} / \mathrm{mL})$ and the $\mathrm{HCl}+\mathrm{PTX}$ group $(16 \pm 2.0 \mathrm{ng} / \mathrm{mL})$ compared to the $\mathrm{PTX}+\mathrm{HCl}$ group $(27.4 \pm 1.9 \mathrm{ng} / \mathrm{mL})$.

\section{Histopatology and morphometric analyses}

The light microscopic appearance of lung tissue of all four groups after $3 \mathrm{~h}$ of mechanical ventilation is shown in Figure 3. In the group Control-MV, pulmonary paren-

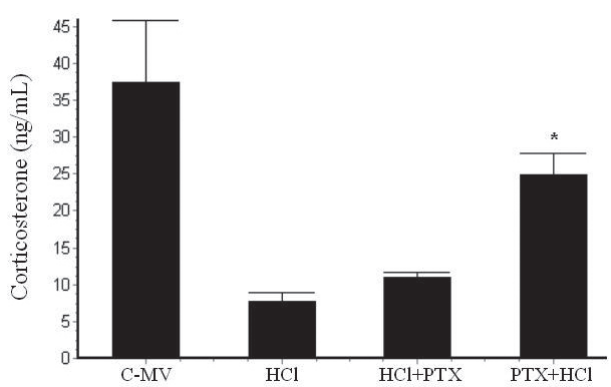

Figure 2 - Effects of $\mathrm{HCl}$ instillation and pentoxyfilline (PTX) pre- or posttreatments on corticosterone levels in BAL from rats under mechanical ventilation. ${ }^{*} p<0.05$ versus the $\mathrm{HCl}$ and the $\mathrm{HCl}+\mathrm{PTX}$ groups. Values are presented as mean $\pm \mathrm{SD}$.

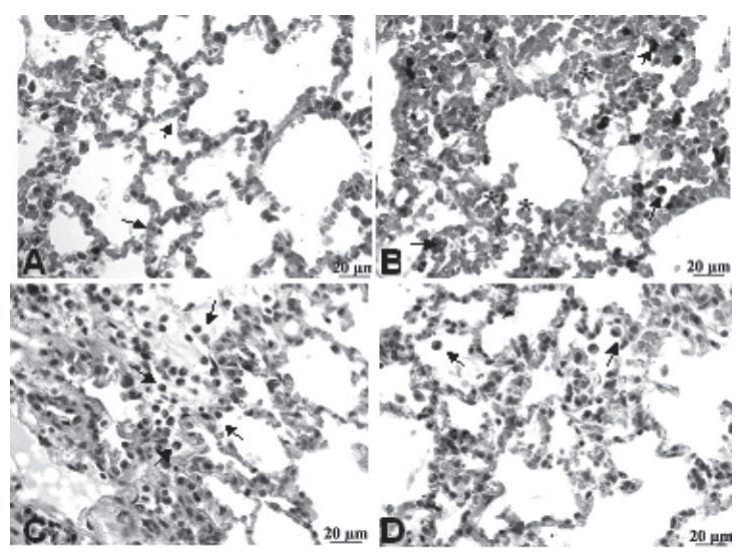

Figure 3 - Photomicrographs of HE-stained rat lungs using 400X magnification. (A) C-MV (control, mechanical ventilation) exhibits dilated and congested alveolar septa (arrows); (B) $\mathrm{HCl}$ group shows macrophages (arrow) and erythrocytes inside alveolus (asterisk); (C) $\mathrm{HCl}+\mathrm{PTX}$ group exhibits some inflammatory infiltration, numerous macrophages, neutrophiles (arrows) and red blood cells; (D) PTX $+\mathrm{HCl}$ group, showing mild alveolar edema and few macrophages in the alveolar lumen (arrow).

chyma showed typical cavities, septs with congested capillaries and few macrophages and neutrophils inside (Figure $3 \mathrm{~A}$ ). In the $\mathrm{HCl}$ group, alveolar hemorrhage, infiltration of macrophages with hemosiderin pigment and alveo- 
lar wall dilation were observed (Figure 3B). In the $\mathrm{HCl}+\mathrm{PTX}$ group, areas of hemorrhage in the alveoli, macrophage influx and dilation of alveolar septae could be observed (Figure $3 \mathrm{C}$ ). In the $\mathrm{PTX}+\mathrm{HCl}$ group, a greatly decreased volume of macrophages and red blood cells infiltrates in lung tissue. (Figure 3D).

In the morphometric analysis, there was an increase of neutrophils (Figure 4) in the $\mathrm{HCl}\left(2.83 \pm 0.5 / \mathrm{mm}^{2}\right)$ and $\mathrm{HCl}+\mathrm{PTX}\left(2.81 \pm 0.5 / \mathrm{mm}^{2}\right)$ groups compared with the control $\left(1.13 \pm 0.3 / \mathrm{mm}^{2}\right)$. A significant difference in this regard $(p<0.05)$ was observed between the $\mathrm{HCl}+\mathrm{PTX}(2.81 \pm$ $\left.0.5 / \mathrm{mm}^{2}\right)$ and $\mathrm{PTX}+\mathrm{HCl}\left(2.2 \pm 0.4 / \mathrm{mm}^{2}\right)$ groups. The macrophage counts (Figure 5) were high in the $\mathrm{HCl}$ and $\mathrm{HCl}+\mathrm{PTX}$ groups $\left(0.82 \pm 0.13 / \mathrm{mm}^{2}\right.$ and $0.43 \pm 0.08 * / \mathrm{mm}^{2}$, respectively; $* \mathrm{p}<0.05)$. The macrophage count was lower in the control and $\mathrm{PTX}+\mathrm{HCl}$ groups $\left(0.25 \pm 0.12 / \mathrm{mm}^{2}\right.$ and $0.26 \pm 0.06 / \mathrm{mm}^{2}$, respectively).

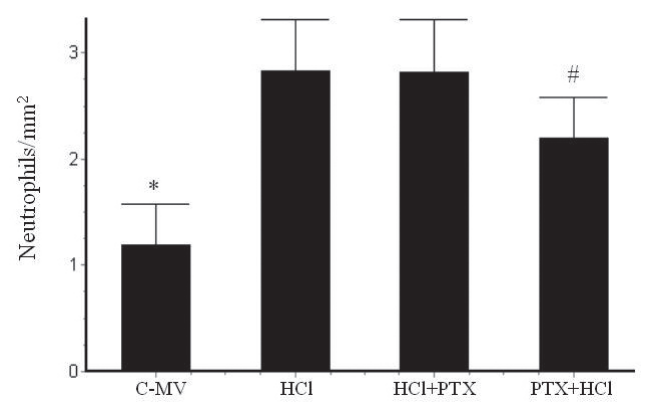

Figure 4 - Effects of PTX on morphometric counts of neutrophils in the lung tissue in the groups $\mathrm{C}-\mathrm{MV}, \mathrm{HCl}, \mathrm{HCl}+\mathrm{PTX}$ and $\mathrm{PTX}+\mathrm{HCl} .{ }^{*} p<0.05$ versus all the other groups, and ${ }^{\#} p<0.05$ versus the $\mathrm{HCl}$ and the $\mathrm{HCl}+\mathrm{PTX}$ groups. Values are presented as mean $\pm \mathrm{SD}$.

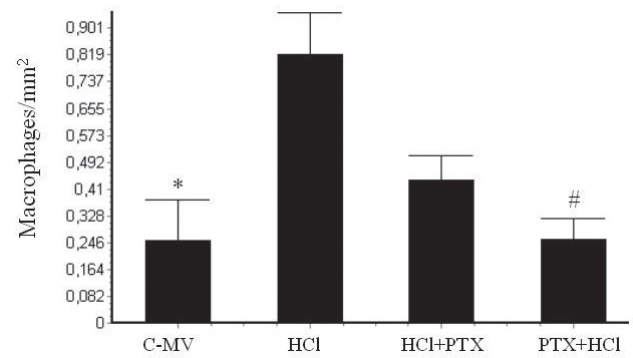

Figure 5 - Effects of PTX on morphometric counts of macrophages per alveolar area in the lung tissue in the groups $\mathrm{C}-\mathrm{MV}, \mathrm{HCl}, \mathrm{HCl}+\mathrm{PTX}$ and $\mathrm{PTX}+\mathrm{HCl}$. . $p<0.05$ versus the $\mathrm{HCl}$ and $\mathrm{HCl}+\mathrm{PTX}$ groups, and ${ }^{\#} p<0.05$ versus the $\mathrm{HCl}$ and the $\mathrm{HCl}+\mathrm{PTX}$ groups. Values are presented as mean $\pm \mathrm{SD}$.

\section{DISCUSSION}

The present study demonstrated that pretreatment with PTX promoted the recovery of $\mathrm{Pa}_{\mathrm{O} 2}$ after lung instillation of $\mathrm{HCl}$ and reduced both cytokine levels and the total protein content in BAL. The histological study among the ex- perimental groups, particularly those with PTX pretreatment, indicated a significant reduction of macrophage and neutrophil infiltrate. On the other hand, PTX administration after $\mathrm{HCl}$ instillation was not able to reduce, nor did it prevent, the disruption of the alveolar surface. The drug was chosen following previous experimental data obtained in our laboratory. ${ }^{18,36}$

We speculate that the findings from the current study may be of significance regarding a number of important related areas. First, pulmonary dysfunction worsens with mechanical ventilation. Second, pretreatment with PTX reduced the pulmonary dysfunction and inhibited TNF-alpha and PMN cells influx into the lung. Third, corticosteroids may play a role in stabilizing the local inflammatory process.

In animals that received $\mathrm{HCl}$ instillation followed by mechanical ventilation (MV), there was a reduction of $\mathrm{Pa}_{\mathrm{O} 2}$; in those post-infused with PTX, the oxygenation improved, and an even better oxygenation level was observed in the group pretreated with PTX. In rabbits, Nishina et al. (1998) demonstrated that pretreatment with lidocaine promoted the recovery of oxygenation after $\mathrm{HCl}$-induced lung lesion model. ${ }^{19}$

In our model, we demonstrated that PTX reduces the lung lesions caused by $\mathrm{HCl}$ instillation, reducing both the total protein content in BAL and edema as assessed by the W/D ratio. Inflammatory mediators traffic neutrophils into the lungs, which causes a protein-rich pulmonary edema, one of the typical features of the pulmonary insult by acid aspiration, essentially because of the endothelial lesion. ${ }^{20}$

Morphometric analysis demonstrated an increase of both macrophages and neutrophils in the lungs previously instilled with $\mathrm{HCl}$. However, an important reduction of both macrophages and neutrophils was observed in lungs of animals pretreated with PTX. Studies by Schreiber and colleagues (2006) demonstrated that the lung tissue of nonmechanically ventilated animals subjected to a unilateral acid instillation produced a strong inflammatory response. ${ }^{21}$

Several animal models of lung lesions are well-described in the literature as completely satisfactory and relevant to human disease states. The animal model used in the present study was chosen in view of the fact that more then $30 \%$ of human cases of acute pulmonary failure/ARDS are associated with gastric contents aspiration. ${ }^{22-24}$

Pretreatment with PTX also reduced the levels of TNF- $\alpha$, and some studies have shown that PTX reduces the haemodynamic equilibrium disruption observed in cases such as hypovolemic shock, endotoxaemic shock, gastric aspiration and TNF-induced pulmonary lesions. ${ }^{25}$

During severe disease, neurohumoral factors, cytokines and endothelins, among others, activate the HPA axis, 
thereby resulting in the production and increase of plasma levels of cortisol. ${ }^{26}$ In rodents, even though the increase of plasma corticosteroids is a normal event in response to stress and lesion, there is some debate on what could be a 'normal' response to stress and how such a response would affect the normal or the deleterious defense mechanisms of the body. ${ }^{27}$ In humans, the rise of circulating cortisol is well-described in both ARDS and the normal stress response. ${ }^{27}$ Besides, low levels of cortisol are associated with the worsening of the organic conditions in patients with sepsis. ${ }^{28}$ Sebaldt et al.(1990) demonstrated that high daily oral doses of glycocorticoids (60 mg prednisone/day) given in the morning for 7 days inhibit the synthesis and the appearance of leukotrienes in the BAL of healthy volunteers, ${ }^{29}$ but the subjects in their study were not under MV. There are diverse, and sometimes opposing, effects of the glucocorticoids, because they are dependent on the cell type upon which these drugs act. ${ }^{30}$

Data reported by Bernard et al. (1987) suggest that high-dose methylprednisolone does not affect the outcome in patients with established ARDS due to sepsis, aspiration or a mixed cause. ${ }^{31}$

The neuroendocrine responses mediated by the HPA axis are associated with various feedback mechanisms. It is conceivable that the reactions to stress have different degrees of specificity, and that they may or may not develop with proper homeostasis maintenance. This can be observed through the corticosterone concentrations in the BAL observed in the present study.

In healthy volunteers, Hubbard et al. (1994) found endogenous BAL levels of cortisone and cortisol of 380 and $153 \mathrm{pg} / \mathrm{mL}$, respectively. ${ }^{32}$ Later, Baker et al. (2000) determined the concentration of cortisol in BALs of 11 patients with acute tuberculosis and 13 healthy volunteers and found that the diseased patients had significantly elevated cortisol levels in BAL. ${ }^{33}$

In addition to $\mathrm{HCl}$-induced stress, which causes per se tissue lesions, MV also caused pulmonary lesions and vasoconstriction, though to a lower degree. Accordingly, various studies have demonstrated an increase of inflammatory mediators produced by the lung after MV. ${ }^{18,34,35}$

In the present study, the observed reduction of corticosterone levels in BALs of the group subjected to $\mathrm{HCl}$ instillation plus MV can be viewed as an indication that the direct chemical stress coupled with the forced ventilation reduced the passage of corticosterone into the alveolar spaces. Such a reduction could be related to the increase of the alveolar pressure caused by MV, which, in turn, would alter the alveolar vascular resistance. This would then be followed by a narrowing of the blood vessels around alveoli, an alteration of the alveolar-arterial gradient and, hence, the pulmonary distensibility. Though this study could not unequivocally prove that mechanical ventilation completely blocked the corticosteroid influx into the alveolar space, several other studies have indicated this possibility. ${ }^{29,31,32}$ The higher concentration of corticosterone in the Control-MV group is certainly not a normal value, and other evaluations in a mechanical ventilation-free group are in order. The measurement of corticosterone in blood samples of the same animal in every time point of the experiment was not possible due to the high volume necessary for the assay $(0.5 \mathrm{~mL}$ per time point), leading to the risk of hypovolemic shock.

\section{CONCLUSION}

In conclusion, the data presented suggest that pentoxifylline modulates the production/release of a proinflammatory cytokine (TNF- \pm ) and inflammatory cells, thereby improving oxygenation during the course of an experimental model of $\mathrm{HCl}$-induced lung inflammation.

\section{ACKNOWLEDGMENTS}

We are especially grateful to Wagner Rogério Souza de Oliveira of the Division of Experimental Surgery (UNIFESP) and Ricardo Santos Simões of the Division of Histology and Structural Biology (UNIFESP). This work was supported, in part, by Fundação de Amparo à Pesquisa do Estado de São Paulo (FAPESP; grant 03/14098-0).

\section{REFERENCES}

1. Pepe PE, Potkin RT, Reus DH, Hudson LD, Carrico CJ. Clinical predictors of the adult respiratory distress syndrome. Am J Surg. 1982;144:124-30.
2. Nader ND, Davidson BA, Tait AR, Holm BA, Knight PR. Serine antiproteinase administration preserves innate superoxide dismutase levels after acid aspiration and hyperoxia but does not decrease lung injury. Anesth Analg. 2005;101:213-9. 
3. Knight PR, Druskovich G, Tait AR, Johnson KJ. The role of neutrophils, oxidants and proteases in the pathogenesis of acid pulmonary injury. Aneshesiology. 1992;77:772-8.

4. Modelska K, Pittet JF, Folkesson HG, Courtney Broaddus V, Matthay MA. Acid-induced lung injury: Protective effect of anti-interleukin-8 pretreatment on alveolar epithelial barrier function in rabbits. Am J Respir Crit Care Med. 1999;160:1450-6.

5. Doerschuk CM, Winn RK, Coxson HO, Harlan JM. CD18-dependent and -independent mechanisms of neutrophil emigration in the pulmonary and systemic microcirculation of rabbits. J Immunol. 1990;144:2327-33.

6. Bodlander FM. Deaths associated with anaesthesia. Br J Anaesth. 1975;47:36-40.

7. Marx GF, Mateo CV, and Orkin LR. Computer analysis of postanaesthetic deaths. Anaesthesiology. 1973;39:54-8.

8. Nagase T, Uozumi N, Ishii S, Kume K, Izumi T, Ouchi Y, et al. Acute lung injury by sepsis and acid aspiration: a key role for cytosolic phospholipase A. Nature Immunol. 2000;1:42-6.

9. Wang W, Tam WF, Hughes CCW, Rath S, Sen R. c-Rel is a target of pentoxifylline-mediated inhibition of T lymphocyte activation. Immunity. 1997;6:165-74.

10. Meng ZH, Dyer K, Billiar TR, Tweardy DJ. Essential role for IL-6 in postresuscitation inflammation in hemorrhagic shock. Am J Physiol Cell Physiol. 2001;280:C343-51.

11. Chrousos GP. The hypothalamic-pituitary-adrenal axis and immunemediated inflammation. N Engl J Med. 1995;332:1351-62.

12. MacLaren R, Jung R. Stress-dose corticosteroid therapy for sepsis and acute lung injury or acute respiratory distress syndrome in critically ill patients. Pharmacotherapy. 2002;22:1140-56.

13. Lipworth BJ, Seckl JR. Measures for detecting systemic bioactivity with inhaled and intranasal corticosteroids. Thorax. 1997;52:476-82.

14. Scapagnini U. Psychoneuroendocrinoimmunology: the basis for a novel therapeutic approach in aging. Psychoneuroendocrinoimmunology. 1992;17:411-20.

15. Sapolsky RM, Krey LC, McEwen BS. The adrenocortical stressresponse in the aged male rat: impairment of recovery from stress. Exp Gerontol. 1983;18:55-64.

16. Ottenweller JE, Tapp WN, Pitman DL, Natelson BH. Interactions among the effects of aging, chronic disease, and stress on adrenocortical function in Syrian hamsters. Endocrinology. 1990;126:102-9.

17. The ARDS Clinical Trials Network. Randomized, placebo-controlled trial of lisofylline for early treatment of acute lung injury and acute respiratory distress syndrome. Crit Care Med. 2002;30:1-6.

18. Oliveira-Junior IS, Pinheiro BV, Silva IDCG, Salomao R, Zollner RL, Beppu OS. Pentoxifylline decreases tumor necrosis factor and interleukin-1 during high tidal volume. Braz J Med Biol Res. 2003;36:1349-57.
19. Nishina K, Mikawa K, Takao Y, Shiga M, Maekawa N, Obara H. Intravenous lidocaine attenuates acute lung injury induced by hydrochloric acid aspiration in rabbits. Anesthesiology. 1998;88:13009.

20. Goldman G, Welbourn R, Klausner JM, Kobzik L, Valeri CR, Shepro D, et al.. Neutrophil accumulations due to pulmonary thromboxane synthesis mediate acid aspiration injury. J Appl Physiol. 1991;70:15117.

21. Schreiber T, Hueter L, Gaser E, Schmidt B, Schwarzkopf K, Rek H et al.. PEEP has beneficial effects on inflammation in the injured and no deleterious effects on the noninjured lung after unilateral lung acid instillation. Intensive Care Med. 2006;35:740-9.

22. Matthay M, Rosen GD. Acid aspiration induced lung injury. New insights and therapeutic options. Am J Respir Crit Care Med. $1996 ; 154: 277-8$.

23. Knight PR, Kurek C, Davidson BA, Nader ND, Patel A, Sokolowski J, et al.. Acid aspiration increases sensitivity to increased ambient oxygen concentration. Am J Respir Cell Mol Biol. 2000;278:L1240-7.

24. Balibrea JL, Arias-Díaz J. Acute respiratory distress syndrome in the septic surgical patient. World J Surg. 2003;27:1275-84

25. Kudoh I, Miyazaki H, Ohara M, Fukushima J, Tazawa T, Yamada H. Activation of alveolar macrophages in acid-injured lung in rats: different effects of pentoxifylline on tumor necrosis factor-alpha and nitric oxide production. Crit Care Med. 2001;29:1621-5.

26. Thompson BT. Glucocorticoids and acute lung injury. Crit Care Med. 2003;31:S253-7.

27. Munford RS, Pugin J. Normal responses to injury prevent systemic inflammation and can be immunosuppressive. Am J Respir Crit Care Med. 2001;163:316-21.

28. Bollaert PE, Charpentier C, Levy B, Debouverie M, Audibert G, Larcan A. Reversal of late septic shock with supraphysiologic doses of hydrocortisone. Crit Care Med. 1998;26:645-50.

29. Sebaldt R, Sheller J, Oates J, Roberts LJ 2nd, FitzGerald G. Inhibition of eicosanoid biosynthesis by glucocorticoids in humans. Proc. Natl. Acad. Sci. USA. 1990;87:6974-8

30. Gilbert KA, Petrovic-Dovat L, and Rannels E. Hormonal control of compensatory lung growth. In: Lung Growth and Development, edited by McDonald JA. New York: Dekker, 1997, p. 627-60.

31. Bernard GR, Luce JM, Sprung CL, Rinaldo JE, Tate RM, Sibbald WJ et al.. High-dose corticosteroids in patients with the adult respiratory distress syndrome. N Engl J Med. 1987;317:1565-70

32. Hubbard WC, Bickel C, Scheimer RP. Simultaneous quantitation of endogenous levels of cortisone and cortisol in human nasal and bronchoalveolar lavage fluids and plasma via gas chromatographynegative ion chemical ionization mass spectrometry. Anal Biochem. 1994;221:109-17. 
Oliveira-Júnior IS et al.

33. Baker RW, Walker BR, Shaw RJ, Honour JW, Jessop DS, Lightman SL et al. Increased cortisol: cortisone ratio in acute pulmonary tuberculosis. Am J Respir Crit Care Med. 2000;162:1641-7.

34. Ricard JD, Dreyfuss D, Saumon G. Ventilator induced lung injury. Eur Respir J. 2003;22:2s-9s.
35. Oliveira-Junior IS, Brunialti MK, Koh IH, Junqueira VB, Salomao R. Effect of pentoxifylline on lung inflammation and gas exchange in a sepsis-induced acute lung injury model. Braz J Med Biol Res. 2006;39:1455-63. 
Clinics vol.63 no.1 February/2008

\section{$\underline{\text { Reference - Page } 77}$}

Replace: Oliveira-Júnior IS de, Maganhin CC, Carbonel AAF, Monteiro CMR, Cavassani SS, Oliveira-Filho RM. Effects of pentoxifylline on tnf-alpha and lung histophatology in hcl-induced lung injury. Clinics. 2008;63(1):77-84.

For: Oliveira-Júnior IS, Maganhin CC, Carbonel AAF, Monteiro CMR, Cavassani SS, Oliveira-Filho RM. Effects of pentoxifylline on TNF-alpha and lung histophatology in HCl-induced lung injury. Clinics. 2008;63(1):77-84.

\section{Abstract - Page 77}

Replace: ...to determine the contents of total proteins, corticosteroid and TNF- $\alpha$.

For: ...to determine the contents of total proteins, corticosterone and TNF- $\alpha$.

Replace: The levels of corticosteroid in BAL and TNF- $\alpha \ldots$ For: The levels of corticosterone in BAL and TNF- $\alpha$... 
Replace: ...corticosteroid in BAL upon lung lesion induced by $\mathrm{HCl}$.

For: ...corticosterone in BAL upon lung lesion induced by $\mathrm{HCl}$.

\section{$\underline{\text { Keyword - Page } 77}$}

Replace: Corticosteroid

For: Corticosterone

\section{Department - Page 77}

Replace: Surgery Center, Department of Surgery...

For: Department of Medicine, Division of Geriatrics and Gerontology...

\section{$\underline{\text { Introduction - Page } 78}$}

Replace: ...(TNF-a) and corticosteroid concentrations in BALs and lung wet-to-dry ratios.

For: ...(TNF- $\alpha)$ and corticosterone concentrations in BALs and lung wet-to-dry ratios.

\section{$\underline{\text { Measurements - Page } 79}$}

Replace: Corticosteroid Detection: Corticosteroids were measured in duplicate using a radioimmunoassay (Coat-ACount Rat Corticosteroid, DPC Diagnostic, CA, USA)...

For: Corticosterone Detection: Corticosterones were measured in duplicate using a radioimmunoassay (Coat-A-Count Rat Corticosterone, DPC Diagnostic, CA, USA)...
Replace: Cytokine Assay: TNF-a

For: Cytokine Assay: TNF- $\alpha$

Figure 1 - Page 80

Replace: Effect of pentoxifylline (PTX) on TNF-a levels... For: Effect of pentoxifylline (PTX) on TNF- $\alpha$ levels...

Figure 3 - Page 80

Replace: ...neutrophiles (arrows) and red blood cells; For: ...neutrophils (arrows) and red blood cells;

\section{Discussion - Page 81}

Replace: Third, corticosteroids may play a role... For: Third, corticosterone may play a role...

\section{Conclusion - Page 82}

Replace: ...proinflammatory cytokine (TNF- \pm ) and inflammatory cells,

For: ...proinflammatory cytokine (TNF- $\alpha)$ and inflammatory cells,

\section{$\underline{\text { Authors - Page } 136}$}

Replace: Miguel Barbero Macial

For: Miguel Barbero Marcial 
This article has received corrections in agreement with the ERRATUM published in Volume 63 Number 2. 